Journal of Asian Earth Sciences

January 2018, Volume 151, Pages 90-100

http://dx.doi.org/10.1016/i.jseaes.2017.10.015

http://archimer.ifremer.fr/doc/00407/51828/

(C) 2017 Elsevier Ltd. All rights reserved.

\title{
Causes of earthquake spatial distribution beneath the Izu-Bonin-Mariana Arc
}

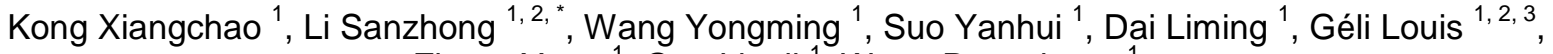 \\ Zhang Yong ${ }^{1}$, Guo Lingli ${ }^{1}$, Wang Pengcheng ${ }^{1}$
}

${ }^{1}$ Key Lab of Submarine Geosciences and Prospecting Techniques, Ministry of Education, and College of Marine Geosciences, Ocean University of China, Qingdao, 266100,China

${ }^{2}$ Laboratory for Marine Geology, Qingdao National Laboratory for Marine Science and Technology,

Qingdao 266235, China

${ }^{3}$ Ifremer, Marine Geosciences Department/Institut Carnot Ifremer-EDROME, BP 70, 29280 Plouzané, France

* Corresponding author : Li Sanzhong, email address : Sanzhong@ouc.edu.cn

\begin{abstract}
:
Statistics about the occurrence frequency of earthquakes (1973-2015) at shallow, intermediate and great depths along the Izu-Bonin-Mariana (IBM) Arc is presented and a percent perturbation relative to P-wave mean value (LLNL-G3Dv3) is adopted to show the deep structure. The correlation coefficient between the subduction rate and the frequency of shallow seismic events along the IBM is 0.605 , proving that the subduction rate is an important factor for shallow seismic events. The relationship between relief amplitudes of the seafloor and earthquake occurrences implies that some seamount chains riding on the Pacific seafloor may have an effect on intermediate-depth seismic events along the IBM. A probable hypothesis is proposed that the seamounts or surrounding seafloor with high degree of fracture may bring numerous hydrous minerals into the deep and may result in a different thermal structure compared to the seafloor where no seamounts are subducted. Fluids from the seamounts or surrounding seafloor are released to trigger earthquakes at intermediate-depth. Deep events in the northern and southern Mariana arc are likely affected by a horizontal propagating tear parallel to the trench.
\end{abstract}


Graphical abstract
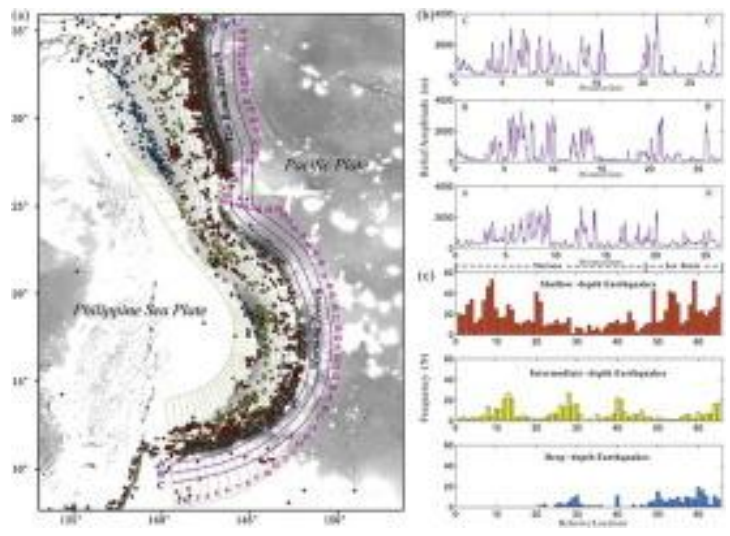

\section{Highlights}

Fluids from the seamounts or surrounding seafloor may cause the seismic segmentation along the IBM. Slab tears in the northern and southern Mariana Arc are likely affecting magmatic and seismic spatial distribution. - The calculated correlation coefficient shows that the subduction rate is an important factor for shallow seismic events along the IBM.

Keywords : Philippine Sea Plate, Pacific Plate, earthquake, seamount, slab tear, subduction rate 


\section{Introduction}

Approximately $80 \%$ of global earthquake occur in subduction zones and different subductions show differences in the magnitude, number and spatial distribution of earthquake events (Kanamori, 1971; Lay et al., 1982; Dai et al., 2016). Many subduction systems show seismic segments, such as the Izu-Bonin-Mariana (Chiu et al., 1991; Jaxybulatov et al., 2013). Some segments are active on historical time scales while some are not (Kelleher and McCann, 1976; Watts, et al., 2010). The seismicity at subduction zones is controlled by different factors, among which: the thermal structure of the upper and lower plates, the dip of the down-going slab, the subduction rate, the presence or not of an accretionay prism, seamounts on top of the subducting plate, slab tear, etc. (Ruff and Kanamori, 1980; Cloos and Shreve, 1996; Gutscher and Westbrook, 2009; Syracuse et al., 2010; Heuret et al., 2011; Xing et al., 2016), raising questions as to what causes are responsible for the seismic distribution along the Izu-Bonin-Mariana (IBM) Arc.

The IBM Arc system delineates the boundary between the Philippine Sea Plate (PSP) and the Pacific Plate in the Western Pacific, and represents a paramount example of trench/arc/back system, along a total length of about $2800 \mathrm{~km}$ (Fig. 1) (Jaxybulatov et al., 2013). It consists of two parts, the approximately linear Izu-Bonin Arc and the curving Mariana Arc (Miller et al., 2006). The two parts result from the complex subducting process of the Pacific Plate, which are characterized by a rate of approximate $9 \mathrm{~cm} / \mathrm{yr}$ along the Izu-Bonin Trench in late Cretaceous and a rate of $5 \mathrm{~cm} / \mathrm{yr}$ along the Mariana Trench in early Jurassic (Seno and Maruyama, 1984; Seno et al., 1993; Miller et al., 2005). The subducting oceanic crust along the IBM Trench is characterized by a 
particularly thin sedimentary cover and numerous seamount chains (Oakley et al., 2008). The IBM interface between the subducting and overriding slabs is regarded as a weakly coupled interface and has been highly segmented (Chiu et al., 1991), and large earthquakes are relatively rare and seismic gaps exist unevenly along the trench axis (Stern et al., 2003).

Some researches reveal the seismic spatial distribution in the Western Pacific is closely related to the landform pattern (Shi, 1998; Stern et al., 2003). Meanwhile, the three-dimensional morphologies of the subducting slab and the hypocenters along the IBM are built to reveal the relevance, and an obvious difference in the hypocenters distribution beneath the IBM Arc may be attributed to the variation in slab morphology caused by the Ogasawara Plateau (Fig. 1) (Gudmundsson and Sambridge, 1998; Miller et al., 2004; Miller et al., 2005; Wei et al., 2012). Seamounts as ubiquitous features of the seafloor in the Western Pacific have an important effect on convergent margin. Once these seamounts enter subduction zone, it will influence the seismicity, especially the size, frequency and spatial distribution by adjusting the coupling between the subducting and overriding plates (Kelleher and McCann, 1976; Scholz and Small, 1997; Watts, et al., 2010). Also, seamount is regarded as a barrier to impede rupture (Das and Watts, 2009), or some subducting seamounts show the characteristics of weak coupling (Mochizuki et al., 2008). Previous researches have shown that subducted seamounts may trigger great, shallow $(<60 \mathrm{~km})$ earthquakes by accumulating local stress during a long time period (Cloos, 1992; Scholz and Small, 1997; Kodairaet al., 2000; Husen and Kissling, 2002; Das and Watts, 2009; Li et al., 2012). However, there is almost no observation for 
intermediate earthquakes triggered by subducted seamounts, due to the low resolution of tomographic imaging that prevent mapping subducted seamounts at great depths. If a subducted seamount chain has reached to intermediate depths $(>60 \mathrm{~km})$, the question addressed here is whether or not it will have an effect on the spatial distribution of earthquakes and by which mechanisms it may affect the distribution. Because subduction zone systems are highly variable, the study is restricted to the specific case of the Izu-Bonin-Mariana Trench System, where an exceptionally high number of Cretaceous Seamount chains are conveyed by the down-going slab into the mantle.

Most of the seismogenic zones are limited to temperatures in the range of $100-150^{\circ} \mathrm{C}$ and $350-400^{\circ} \mathrm{C}$ (Oleskevich et al., 1999; Currie et al., 2002; Heuret et al., 2011), but slab tear may control the spatial distribution of young magmatism, and magmatism can change original slab temperatures (Gideon et al., 2008). Therefore, some seismic gaps usually exist nearby the slab tear. Evidence of slab tear SW of Guam is first proposed, based on hypocenter distribution (Gvirtzman and Stern, 2004). A three-dimensional visual model is constructed beneath the Mariana Arc by extracting the maximum contrast in P-wave velocity contours (Miller et al., 2006). The result shows a probable slab tear oriented approximately E-W at 75-200 km depth characterized by no seismicity at depths $>200 \mathrm{~km}$ (Fig.1).

Some statistical results show that earthquake magnitude is related to plate motion, and the faster subduction rate may enhance the seismicity (Ruff and Kanamori, 1980; Jarrard, 1986). But, there is also a contradictory result at other faster subduction, such as the Tonga and the New Hebrides (Heuret et al., 2011). Thermal structure may have an 
effect on the earthquakes, and thermal parameter defined as the product of convergence rate and slab age reflects thermal structure in a sense. However, no relationship between seismogenic zone and convergence rate or age is confirmed (Pacheco et al., 1993; Gutscher and Westbrook, 2009). A global statistical analysis presents that most of geometrical parameters of the subduction zone are uncorrelated with the number of plate interface earthquakes, but the subduction rate may be the first-order controlling parameter determining some mechanical behaviors (Heuret et al., 2011). In addition, the asymmetric spreading affecting the plate motion needs to be considered (Heuret and Lallemand, 2005). Seismic distribution along IBM may be also affected by a Euler polar lied at $8^{\circ} \mathrm{N}$, $137.3^{\circ}$ E, around which the Pacific plate goes counterclockwise to the Philippine Sea plate (DeMets et al., 1994; Stern et al., 2003; Xing et al., 2016).

This paper shows how the three factors including seamounts, slab tear and subduction rate may indeed be regarded as important factors controlling the spatial distribution of earthquakes along the IBM Arc. Statistics along the different IBM trench segments and a comparison between relief amplitude and earthquakes number at different depths imply that if the seamount chains have been subducted to the deep ( $>60 \mathrm{~km})$, these seamounts may be related to earthquakes at intermediate-depth (60-300 km). Meanwhile, percent perturbations relative to the $\mathrm{P}$ wave mean value (LLNL-G3Dv3, Simmons et al.,2012) show that the subducted slab may have undergone tears beneath the IBM Arc, which has an effect on magmatic and seismic spatial distribution. The correlation coefficient is calculated to prove that the subduction rate is an important factor for shallow seismic events along the IBM. 


\section{Seismicity and relief}

\subsection{Seismicity}

Epicenters are plotted in Fig.2a, which marks a well-defined Wadati-Benioff zone along the IBM Arc. These earthquakes are derived from the catalog of U.S. Geological Survey, and magnitudes are more than Mw5 during 1973-2015. To further understand the spatial distribution of earthquakes, the IBM subduction zone is divided into 65 parts (Fig.2a). Each part is made of two lines that produce a $\sim 50-\mathrm{km}$-wide band along the trench. And these lines are vertical to the trench and top boundary of the subducting Pacific plate (Slab 1.0) as much as possible (Hayes et al., 2012). Different depth earthquakes are matched spatially with each part. Statistic (Fig.2c) shows the relationship between the number of earthquakes and relative location along the IBM Trench. Three results stand respectively for shallow-depth $(<60 \mathrm{~km})$, intermediate-depth $(60-300 \mathrm{~km})$ and deep-depth $(>300 \mathrm{~km})$ earthquakes. Fig.2c shows an obvious difference of earthquakes distribution between the Izu-Bonin arc and the Mariana arc.

Between the Mariana arc and the Izu-Bonin arc there is a dramatic difference in spatial distribution of earthquakes. For the Mariana subducting system, most shallow-depth events are concentrated in the southern part, and the number of earthquakes decreases along the curving Mariana arc from south to north. Intermediate-depth events are geographically distributed in 3 groups (Fig.2c). But, there are almost no great-depth events except along the northern Mariana segment. For the Izu-Bonin subducting system, shallow events present a rising trend from south to north 
except local shallow earthquakes including upper plate earthquakes and flexural earthquakes (Lallemand, 2014), and intermediate-depth events are relatively rare. Deep events are concentrated where the slab dip is changing from vertical to horizontal (Miller et al., 2004). The seismic statistic is consistent with previous result (Jaxybulatov et al., 2013; Xing et al., 2016).

\subsection{Relief Amplitude And Focal Mechanism}

Relief amplitude, derived from the General Bathymetric Chart of the Oceans (GEBCO), shows the possible effects of seamount on the earthquake distribution along the IBM subducting system. The relief amplitude of the seafloor is the difference value between maximum and minimum bathymetry. The Neighborhood Statistics method of ArcGIS is used to calculate the maximum and minimum bathymetry. The precision of the bathymetry data is 1 arc-minute, and the range of the Neighborhood Statistics method is a rectangle of $10 \times 10$ cells. Fig.2b shows three sections (A-A', B-B', C-C') of relief amplitude. Three peaks in Fig. 2b stand respectively for the Caroline Island Ridge, the Dutton Ridge and the Marcus-Necker Ridge.

Fig.3 shows CMT earthquakes of three sections from Fig.2 which are vertical to the trench and top boundary of the subducting Pacific plate and show go across the clusters of intermediate-depth events. Free-air gravity anomaly reflects the variation of the topography, and the data is from Submap (Sandwell and Smith, 1997). There is a greater depth trend for the intermediate-depth events from south to north. Focal mechanisms present that southern Mariana segment (Fig.3 D-D') contains normal, reverse and dip-slip fault. Central segment (Fig.3 E-E') predominately implies reverse fault, and deep CMT 
earthquakes represent normal fault. Two intermediate-depth clusters of northern segment (Fig.3 F-F') stand respectively for upper normal fault and lower reverse fault.

\section{Velocity model}

Here, the global P-wave velocity model (LLNL-G3Dv3) is used (Simmons et al., 2012). This model based on $P$ and $P n$ arrivals is re-processed within a spherical tessellation using global multiple-event locations (Simmons et al., 2012). The images of six sections are derived from percent perturbation relative to the $\mathrm{P}$ wave mean value in each layer. High abnormal values stand for old lithosphere of the Pacific Plate below the IBM Arc, and vertical slices along the cross sections present the geometry shape of the subducted slab that is basically consistent with previous researches (Zhao, 2012; Liu et al., 2013; Liu and Zhao, 2015; Zhao, 2015). Earthquake $\left(\mathrm{M}_{\mathrm{w}}>5\right)$ hypocenters for the 1973-2015 period (from USGS catalog) are plotted. In addition, the upper boundary of the subducting slab beneath the IBM Arc, which is a three-dimensional compilation (Slab 1.0) of the subduction geometry based on some independent data catalogs such as historic earthquakes, CMT solutions, active seismic profiles, etc. (Hayes et al., 2012), is matched to the image.

Though the result (Fig.4a) shows some deviations between inversion image and slab interface data (Slab 1.0), due to the scarcity of local seismometer stations in the Mariana arc, it can still present deep structure. Sections A-A' and B-B' in Fig.4 show steep dipping Pacific Plate, and an approximately horizontal old Pacific plate is retained from $400 \mathrm{~km}$ 
to $660 \mathrm{~km}$. Moreover, a distinct gap at about $300-400 \mathrm{~km}$ is interpreted as a probable slab tear (Miller et al., 2004; Miller et al., 2005). Some shallow hypocenters are mainly distributed along the top interface of the subducting slab and the deep ( $>300 \mathrm{~km})$ earthquakes are concentrated where the slab dip changes from vertical to horizontal, and these hypocenter clusters show a seismic gap from $200 \mathrm{~km}$ to $380 \mathrm{~km}$. Sections D-D', E-E' and F-F' (Fig.4) indicate that the Pacific Plate is penetrating vertically into lower mantle. Like in most subduction zones, intense shallow-depth earthquakes usually occur in the forearc region near the upper boundary of the subducting slab. Section E-E' (Fig.4) also present a seismic absence from $300 \mathrm{~km}$ to $400 \mathrm{~km}$.

\section{Discussion}

The thermal structure of the subducting slab plays an important role on triggering earthquakes by controlling the rheological properties of rocks. The cause of earthquakes is complicated, but different explanations have been proposed for different-depths earthquakes. A "stick-slip" mechanism (Brace and Byerlee, 1966) causing shallow earthquakes is widely accepted. Dehydration embrittlement (Haemyeong and Harry, 2004; Ii et al., 2010) may be the cause of the intermediate-depth earthquakes. For earthquakes at deep-depths, a main viewpoint is transformation-induced faulting (Schubnel et al., 2013; Zhan et al., 2014). These explanations are important references for interpreting seismic spatial distribution.

A common model of seismic spatial distribution about the Izu-Bonin and the Mariana 
arc is constructed (Fig.5). Like most cold Pacific subduction zones (Kong et al., 2016), the Izu-Bonin arc is characterized by an intense shallow-depth earthquake activity along the upper boundary of the subducting slab. When temperature and pressure rise with descending depth, intermediate-depth earthquakes may occur in two distinct layers. The upper layer is concentrated near the subducting oceanic crust and the lower layer near the subducting oceanic mantle (Hasegawa et al., 1994). Both layers can be respectively interpreted by dehydration of oceanic crust and mantle (Haemyeong and Harry, 2004; Ii et al., 2010). Near the $410 \mathrm{~km}$ discontinuous interface, nearly no earthquakes appear due to high temperature and pressure. Deep earthquakes are mainly concentrated where the dipping slab becomes horizontal (Fig.5), which may be caused by transformation-induced faulting (Jiang and Zhao, 2011; Schubnel et al., 2013; Zhan et al., 2014). However, compared to other Pacific subduction zones, the Mariana arc presents different seismic distribution and is highly segmented (Fig.2c) along the curving Mariana trench axis. Three peaks (Fig.2c) standing for intermediate-depth seismic clusters, of which both sides show seismic gaps (Fig.6), seem be abnormal because nearly no seismic events occur at the same depth along the Mariana arc. Deep events occur in the northern Marina, and nearly no deep events appear beneath the southern Mariana and the Ogasawara plateau. Some causes from previous researches are summarized, and a probable hypothesis is that seamounts may also play a role on adjusting seismic local distribution.

\subsection{Seamount}

Numerous seamounts are scattered over the seafloor in the Western Pacific (Fryer 
and Smoot, 1985). These ubiquitous features of the seafloor eventually subduct into the deep mantle with the plates motion (Watts et al., 2010; Staudigel and Clague, 2010). As a classic subduction system, the IBM Arc keep relatively steep subducting angle, and it has nearly no thick accretionary wedge from sediment of the Pacific Plate and only has thin trench fills. Moreover, many normal faults have cut the subducting slab and seamounts riding the slab from the outer rise to the IBM trench axis (Oakley et al., 2008). Before most materials from the Pacific plate enter directly the Subduction Factory, seamounts may have been truncated near the subducting inlet and just generated small earthquakes (Cloos and Shreve, 1996; Staudigel et al., 2010). Some serpentinized seamounts are located $\sim 50-70 \mathrm{~km}$ west of the trench axis, and their formations may be related to the eruption of hydrated fore-arc mantle, but there is no direct evidence (Oakley et al., 2008). Two seamount types are presented: off-ridge seamounts formed on a strong plate far away from a mid-ocean ridge and on-ridge seamounts formed on a weak plate near a ridge (Koppers and Watts, 2010). At present, most seamounts lying on the Pacific seafloor near the Mariana trench are the off-ridge type. The kind of seamount with high elastic thickness keeps less compensation state before it is subducted into the trench (Watts et al., 2010). That means that the subducted seamounts beneath the trench may have less buoyancy and show a weak coupling to the overriding plate. There was no obvious geophysical evidence about the long-term sediment accretion of the inner Mariana trench and the uplift of the overriding plate caused by seamount subduction (Oakley et al., 2008). It means that the subducted seamounts may erode the toe of the overriding plate (Dominguez et al., 1998). Subduction erosion can thicken the subduction 
channel at shallow-depth, therefore prevent the subducted seamounts from causing seismogenic asperities (Cloos and Shreve, 1996). Our results (Fig.2b,c) imply no obvious correlation between seamounts and shallow earthquakes in the northern Mariana arc. It also explains some existing shallow seismic gaps due to weak coupling. However, in the southern Mariana and near the Ogasawara plateau, higher relief amplitude and numerous shallow-depth events implies probable relationship between them. The frequency of events at the cross points of island-arcs and submarine ridges is more intense than surrounding seafloor (Shi, 1998).

Seamount chains subducted to depths $>60 \mathrm{~km}$, if any, could control the spatial locations of intermediate earthquakes. Though previous workers have observed the shapes of some shallow subducted seamounts by seismic reflection (Kodaira et al., 2000; Mochizuki et al., 2008; Nishizawa et al., 2009; Singh et al., 2011), almost no direct evidence about the shape of seamounts at deeper depths is presented due to the lack of resolution of seismic imaging techniques. In addition, latent metamorphism between the mantle wedge and the subducted seamounts may have consumed seamounts or change their shape. Usually, the thermal structure of the Pacific plate controls the spatial distribution of earthquakes (Fig.5) like at the Izu-Bonin arc, where there are only few intermediate-depth earthquakes due to stable slide (Hirauchi and Katayama, 2013). But, Fig.2b,c shows seismic segments at intermediate-depth along the Mariana arc. A probable hypothesis is that these dense intermediate-depth events along the Mariana arc may relate to dehydration of the mechanism of seamounts subduction. Maybe, seamount chains have persisted to a deeper depth $(>60 \mathrm{~km})$ beneath the Mariana arc. In fact, the weak coupling 
between the overriding plate and the subducted plate beneath the Mariana arc increase the likelihood. Fluids are mainly derived from sediment, crust and oceanic mantle. Thickened subduction channels bring numerous hydrous materials into the deep by subduction erosion and sediments from the subducting plate itself. Moreover, normal faults from the outer rise to the trench axis cut seamounts and surrounding seafloor, and breakup and fracturing of these seamounts provide pathways for fluids even to serpentinize the oceanic mantle (Ranero et al., 2003). Seamounts smaller than $40 \mathrm{~km}$ in diameter may fracture to a greater degree than the surrounding sea floor, whereas larger seamounts $(40-100 \mathrm{~km})$ may be directly cut into a series of blocks by en-echelon fracture near the trench axis (Fryer and Smoot, 1985). Numerous normal faults from the outer rise to the Mariana trench axis are distributed nearby the subducting seamount (Oakley et al., 2008). More fluids are penetrating into oceanic crust or oceanic mantle of thick seamounts. When seamounts themselves or surrounding seafloor with high degree of fracture persist to deeper depth with the subducting plate, excessive fluids are released to trigger intermediate-depth seismic events.

Though breakup and fracturing of the slab caused by the mechanism of seamounts subduction may play an important role on the distribution of intermediate-depth earthquake, the cause of distribution from fracturing of seamounts themselves or normal seafloor is not confirmed. Because Fig.2 shows locations of three peaks of intermediate-depth earthquakes are not well corresponding to ones of three high relief amplitudes. The focal mechanism of intermediate-depth events (Fig.3) implies that the fault orientations in the southern Mariana is complicated. Subduction orientations is NW 
and subduction rate is low. Whether or not the Caroline Island is subducted into the Mariana Trench need be still verified. Part focal mechanisms of intermediate events in the northern segment stand for normal fault, so fluids from subduction of normal seafloor is more effective. But, the subduction mechanism of the Ogasawara Plateau may play an indirect role on increasing the fluids of oceanic crust by increasing the fracture degree of the surrounding seafloor. Subduction orientations in the central Mariana is eastward and focal mechanisms predominately represent reverse fault. Intermediate events is more likely to be related to subduction of the Dutton Ridge. In addition, before seamounts are subducted into the deep, their states are rarely known. If these seamounts are on-ridge type, they may have flexing oceanic crust beneath them, or, the subducting angle of the Mariana arc is not vertical to the mantle. These conditions may be different from present ones. In conclusion, these lithospheric anomalies lied in the end of the western Pacific may disturb the common subduction and have a profound effect on dynamic process of plate converge, thermal structure and stress state.

\subsection{Slab tear}

The curving Mariana arc may be related to northern Marcus-Necker Ridge and southern Caroline Island Ridge (Miller et al., 2006). Two local collisional events cause slab tearing, breaking, or the asthenospheric upwelling. Slab tearing may also be an important cause of the segmented subduction zone (Woodcock and Daly, 1986; Gideon et al., 2008). Most seismic events are distributed along the top boundary of the subducting plate, so slab tear or breaking can lead to the mismatch of seismic spatial distribution. A 
slab tear existing beneath the southern of the Mariana arc is proposed by seismic distribution (Fig.1) (Gvirtzman and Stern, 2004). A probable near-vertical slab tear which is $14.5^{\circ} \mathrm{N}$, between $143.5^{\circ} \mathrm{E}$ and $146.5^{\circ} \mathrm{E}$ (Fig.1) is also revealed by extracting the $\mathrm{P}$ wave velocity (Miller et al., 2006). Fig.4 (C-C', D-D') shows the subducted oceanic crust near the Ogasawara plateau has broken up and low-velocity materials are disturbing it. These tears or breaking which have been confirmed or are unknown along the Mariana arc are inferred to be the result of the backward migration of the Pacific Plate. They can accommodate the bending plate and allow the subducted oceanic crust to continue the curving shape at depth (Fryer et al., 2003; Gvirtzman and Stern, 2004; Miller et al., 2006; Chen et al., 2014).

The rollback of the subducting slab in the Italian region by seismic tomography is investigated and concluded that slab tear play an important role in controlling the spatial distribution of young magmatism (Gideon et al., 2008). Similarly, there exists fails rather than simply bends for the subducting plate along the Mariana trench (Oakley et al., 2008). This is consistent with the result of Fig.4. The result of P- and S- anomalies also show that the seismic clusters beneath the northern and southern Mariana lied in the low-velocity material (Jaxybulatov et al., 2013). Therefore, tears or internal breakoff of the subducting plate beneath the Mariana arc may affect magmatic spatial distribution which will promote the segmentation subduction. Northern and southern Mariana, which show a short or narrow plate shape (Fig.6), may have undergone a horizontal propagating tear parallel to the trench (Gideon et al., 2008). After this, low-velocity materials occupy the positions of the subducting slab. This also interprets that both parts have almost no 
deep earthquakes $(>300 \mathrm{~km})$. Deep focal mechanisms in the central Mariana segment (Fig.3 E-E') show normal faults which are similar to the deep events beneath the Izu-Boin arc (Miller et al., 2004). But, fault orientation of these CMT events do not show property of bending slab.

The geometry and morphology of the subducting Pacific Plate are shown by extracting the maximum contrast of P-wave from tomographic data (Miller et al., 2004). The three-dimensional model shows the discontinuous block at about $350-420 \mathrm{~km}$ beneath the Izu-Bonin arc, and a cluster of earthquakes is located in this absent block. Focal mechanisms indicate a probable NNW-SSE strike which is interpreted to accommodate the strain due to the large variation in geometry. The result from Fig.4 B-B' is consistent with the discontinuous block. A "seismic gap" is located above the seismic cluster. Slab from $300 \mathrm{~km}$ to $400 \mathrm{~km}$ may be torn beneath the Izu-Bonin arc (Fig.4), and the slab tear cause decoupling between slab interface and mantle. Therefore, the absence of intermediate earthquakes may be a result of slab tear. Fig.6 shows a three-dimensional shape of the subducting slab and earthquakes distribution.

\subsection{Subduction Rate and Spreading Half-Rate}

Seismic distribution along IBM is controlled integrally by a Euler polar lied at $8^{\circ} \mathrm{N}$, $137.3^{\circ}$ E (DeMets et al., 1994), where the closer the subducting plate, the slower the convergence rate (DeMets et al., 1994; Xing et al., 2016). Seismic coupling is controlled by convergence rate and lithosphere age, which determine the horizontal and sinking rates, 
respectively (Ruff and Kanamori; 1980). However, the result stands for a statistical relation between the earthquake magnitude and other factors. Here, Fig.1 shows lithosphere age of the Pacific Plate is 155-135 Ma from south to north along the IBM, and convergence rate which is an absolute motion of the subducting Pacific Plate is about 115-118 mm/yr along IBM (Gripp and Gordon, 2002). Fig.7a shows an increasing trend of subduction rate which is a relative motion between the Pacific Plate and the Mariana microplate from south to north (Gripp and Gordon, 2002). But, northern Marcus-Necker Ridge and southern Caroline Island Ridge seem disturb the subduction velocity. There is a descending trend from the Caroline Island Ridge to northern Marcus-Necker Ridge. The trend along the IBM is broadly consistent with the shallow events (Fig.2). A comparison (Fig.7b) between subduction rate and shallow seismic events (Fig.2c) along the IBM is presented and the correlation coefficient is 0.605 . It means subduction rate is an important factor for the frequency of shallow events along the IBM. But, the relevance does not apply to intermediate and deep events.

The effect of the spreading half-rate is considered and the asymmetric spreading rate is presented based on analysis of bathymetric and magnetic data along the Mariana Ridge (Deschamps and Fujiwara, 2003; Yamazaki et al., 2003; Deschamps et al., 2005; Seama and Okino, 2015). Fig.8 shows faster spreading in the west side of the Mariana spreading center compare to the east side. Half spreading rate is $33 \mathrm{~mm} / \mathrm{y}$ on the western side and 13 $\mathrm{mm} / \mathrm{y}$ on the eastern side at $12^{\circ} 10^{\prime} \sim 13^{\circ} 50^{\prime}$, and the low viscosity in the mantle wedge may cause the asymmetric spreading (Seama and Okino, 2015). Half-spreading rate is two or three times on the western side than on the eastern side at $17^{\circ} 40^{\prime} \sim 19^{\circ} 50^{\prime}$, and 
the cause may be accommodation of large fault lied on the eastern side of the spreading axis, or the vertical subducted Pacific Plate prevents the westward motion of the Mariana microplate (Deschamps and Fujiwara, 2003). In addition, half-spreading rate in the west side is larger than one in the east side at $20^{\circ} \sim 24^{\circ}$, which are attributed to two different ways: abundant magma supply and amagmatic extension (Yamazaki et al., 2003). The cause of asymmetric spreading is complicated, and the spreading center has been segmented highly, even if the adjacent spreading axis may be also affected by different causes. Due to incomplete data, the correlation between earthquakes and spreading half-rate is not confirmed. However, according to present spreading half-rate data, there is no direct correlation between them.

In a word, shallow earthquakes along the Mariana arc are affected together by subduction rate, seamount subduction, lithosphere age, tectonic erosion and approximately vertical subduction.

\section{Conclusions}

Statistics about earthquakes (1973-2015) at shallow, intermediate and deep depth along the IBM Arc present the latent relationship between relief amplitude of seafloor and seismic occurrence frequency. A probable hypothesis is proposed that fluids retained in the subducting oceanic crust and mantle due to the mechanism of seamounts subduction are released to trigger seismic events at intermediate-depth.

The result of percent perturbation relative to the $\mathrm{P}$ wave mean value (LLNL-G3Dv3) implies that the subducted slab seem have undergone part tears or breakoff beneath the 
IBM Arc, especially the Mariana arc, which is affecting magmatic and seismic spatial distribution.

The correlation coefficient is 0.605 between subduction rate and the frequency of shallow seismic events along the IBM. Therefore, subduction rate is an important factor for shallow seismic events.

This paper reveals probable causes for seismic spatial distribution along the IBM Arc. Our future work will focus on the deeper subducted seamounts and slab tears by high-resolution seismic tomographic images which is helpful to better understand subduction process.

\section{Acknowledgements}

Thanks to two anonymous reviewers for constructive suggestions which improved the quality of the manuscript. We thank earthquake data from USGS catalog, global P-wave velocity model (LLNL-G3Dv3, Simmons et al., 2012), Slab 1.0 (Hayes et al., 2012). Thanks to software ArcGIS, Matlab, Submap. Funding for this research was provided by the NSFC project (Grants 41325009, 41402172, 41190072, 41502185 and 41502321). This work was also supported financially by the National Programme on Global Change 
and Air-Sea Interaction, SOA (No.GASI-GEOGE-01) and Taishan Scholor Program and Aoshan Talents Program (2015ASTP-0S10) to Prof. Sanzhong Li.

\section{References}

Amante, C., Eakins, B.W., 2009. ETOPO1 1 Arc-Minute Global Relief Model: Procedures, Data Sources and Analysis. NOAA Technical Memorandum NESDIS NGDC-24. National Geophysical Data Center, NOAA. doi:10.7289/V5C8276M

Brace, W.F., Byerlee, J.D., 1966. Stick-slip as a mechanism for earthquakes. Science 153(3739), 990-992.

Chen, P.F., Chen, K.X., Cheng, H.Y., 2014. Frequent excitations of t, waves by earthquakes in the South Mariana Arc. Journal of Asian Earth Sciences 98, 50-60.

Chiu, J.M., Isacks, B.L., Cardwell, R.K., 1991. 3-D configuration of subducted lithosphere in the western Pacific. Geophysical Journal International 106(106), 99-111.

Cloos, M., 1992. Thrust type subduction zone earthquakes and seamount asperities: A physical model for earthquake rupture. Geology 20, 601-604.

Cloos, M., Shreve, R.L., 1996. Shear-zone thickness and the seismicity of Chilean- and Marianas-type subduction zones. Geology 24(2), 107-110.

Currie, C.A., Hyndman, R.D., Wang, K., Kostoglodov, V., 2002. Thermal models of the mexico subduction zone: implications for the megathrust seismogenic zone. Journal of Geophysical Research Atmospheres 107(B12), 2370.

Das, S., Watts, A.B., 2009. Effect of subducting seafloor topography on the rupture 
characteristics of great subduction zone earthquakes. Subduction Zone Geodynamics. Springer Berlin Heidelberg 103-118.

Demets, C., Gordon, R.G., Argus, D.F., Stein, S., 1994. Effect of recent revisions to the geomagnetic reversal time scale on estimates of current plate motions. Geophysical Research Letters 21(20), 2191-2194.

Deschamps, A., Fujiwara, T., 2003. Asymmetric accretion along the slow-spreading Mariana Ridge. Geochemistry Geophysics Geosystems 4(10), 237-237.

Dominguez, S., Lallemand, S., Malavieille, J., Von, H.R., 1998. Upper plate deformation associated with seamount subduction. Tectonophysics 293(3), 207-224.

Dziewonski, A. M., Chou, T., Woodhouse, J. H, 1981. Determination of earthquake source parameters from waveform data for studies of global and regional seismicity. Journal of Geophysical Research Atmospheres 86(NB4), 2825-2852.

Fryer, P., Smoot, N.C., 1985. Processes of seamount subduction in the Mariana and Izu-Bonin trenches. Marine Geology 64(1-2), 77-90.

Fryer, P., Becker, N., Appelgate, B., Martinez, F.,Edwards, M., Fryer, G., 2003. Why is the Challenger Deep so deep? Earth and Planetary Science Letter 211, 259-269.

Gideon, R., Massimo, G., Lucente, F.P., Angelo, P., Miller, M.S., 2008. Kinematics of slab tear faults during subduction segmentation and implications for Italian magmatism. Tectonics 27(TC2008), 366-389.

Gripp, A.E., Gordon, R.G., 2002. Young tracks of hotspots and current platevelocities. Geophysical Journal International 150(150), 321-361.

Gutscher, M.A., Westbrook, G.K., 2009. Great earthquakes in slow-subduction, low-taper 
margins. Frontiers in Earth Sciences 119-133.

Gvirtzman, Z., Stern, R.J., 2004. Bathymetry of Mariana trench-arc system and formation of the Challenger Deep as a consequence of weak plate coupling. Tectonics 23(2), $117-128$.

Ólafur Gudmundsson, Sambridge, M., 1998. A regionalized upper mantle (RUM) model. Journal of Geophysical Research Atmospheres 103(B4), 7121-7136.

Haemyeong, J.,Harry, W. Green II., 2004. Experimental faulting of serpentinite during dehydration: implications for earthquakes, seismic low-velocity zones, and anomalous hypocenter distributions in subduction zones. International Geology Review 46(12), 1089-1102.

Hasegawa, A., Horiuchi, S., Umino, N., 1994. Seismic structure of the northeastern Japan convergent margin: a synthesis. Journal of Geophysical Research Solid Earth 99(B11), 22295-22311.

Hayes, G.P., Wald, D.J., Johnson, R.L., 2012. Slab1.0: a three-dimensional model of global subduction zone geometries. Journal of Geophysical Research Atmospheres 117(B1), 180-198.

Heuret, A., Lallemand, S., 2005. Plate motions, slab dynamics and back-arc deformation. Physics of the Earth and Planetary Interiors 149(1-2), 31-51.

Heuret, A., Lallemand, S., Funiciello, F., Piromallo, C., Faccenna, C., 2011. Physical characteristics of subduction interface type seismogenic zones revisited. Geochemistry Geophysics Geosystems 12(1), 384-398.

Hirauchi, K.I., Katayama, I., 2013. Rheological contrast between serpentine species and 
implications for slab-mantle wedge decoupling.Tectonophysics 608(6), 545-551.

Husen, S., Kissling, E., Quintero, R., 2002. Tomographic evidence for a subducted seamount beneath the Gulf of Nicoya, Costa Rica: The cause of the $1990 \mathrm{Mw}=7.0$ Gulf of Nicoya earthquake. Geophysical Research Letters 29(8), 79-1-79-4.

Ii, H.W.G., Chen, W.P., Brudzinski, M.R., 2010. Seismic evidence of negligible water carried below 400-km depth in subducting lithosphere. Nature 467(7317), 828-831.

Jarrard, R.D., 1986. Relations among subduction parameters. Reviews of Geophysics 24(2), 217-284.

Jaxybulatov, K., Koulakov, I., Dobretsov, N., 2013. Segmentation of the Izu-Bonin and Mariana slabs based on the analysis of the Benioff seismicity distribution and regional tomography results. Solid Earth 4(1), 59-73.

Jiang, G., Zhao, D., 2011. Metastable olivine wedge in the subducting Pacific slab and its relation to deep earthquakes. Journal of Asian Earth Sciences 42(6), 1411-1423.

Kanamori, H., 1971. Great earthquakes at island arcs and the lithosphere. Tectonophysics 12(3), 187-198.

Kelleher, J., McCann, W. 1976. Buoyant zones,great earthquakes, and some predictions. Journal of Geophysical Research 81(4), 885-896.

Koppers, A.A.P., Watts, A.B., 2010. Intraplate Seamounts as a Window into Deep Earth Processes. Oceanography 23(1), 42-57.

Kodaira, S., Takahashi, N., Nakanishi, A., Miura, S.,Kaneda, Y., 2000. Subducted seamount imaged in the rupture zone of the 1946 Nankaido earthquake. Science 289(5476), 104-106. 
Lallemand, S., 2014. Active continental margin. Encyclopedia of Marine Geosciences. DOI 10.1007/978-94-007-6644-0_102-2.

Lay, T., Kanamori, H., Ruff, L.J., 1982. The Asperity Model and the Nature of Large Subduction Zone Earthquakes. Earthquake Prediction Research 1(1), 3-71.

Miller, M.S., Kennett, B., Lister, G.S., 2004. Imaging changes in morphology, geometry, and physical properties of the subducting Pacific plate along the Izu-Bonin-Mariana arc. Earth and Planetary Science Letters 224(3), 363-370.

Miller, M.S., Gorbatov, A., Kennett, B.L.N., 2005. Heterogeneity within the subducting Pacific slab beneath the Izu-Bonin-Mariana arc: Evidence from tomography using 3D ray tracing inversion techniques. Earth and Planetary Science Letter 235, $331-342$

Miller, M.S., Kennett, B.L.N., Toy, V.G., 2006. Spatial and temporal evolution of the subducting Pacific plate structure along the western Pacific margin. Journal of Geophysical Research 111(B2), 1-5.

Mochizuki, K., 2008. Weak interplate coupling by seamounts and repeating $\mathrm{M} \sim 7$ earthquakes. Science 321, 1194-1197.

Nishizawa, A., Kaneda, K., Watanabe, N., Oikawa, M., 2009. Seismic structure of the subducting seamounts on the trench axis: Erimo Seamount and Daiichi-Kashima Seamount, northern and southern ends of the Japan Trench. Earth Planets and Space 61(3), e5-e8.

Oakley, A.J., Taylor, B., Moore, G.F., 2008. Pacific plate subduction beneath the central Mariana and Izu-Bonin fore arcs: New insights from an old margin. Geochemistry 
Geophysics Geosystems 9(6), 3043-3061.

Oleskevich, D.A., Hyndman, R.D., Wang, K., 1999. The updip and downdip limits to great subduction earthquakes: thermal and structural models of Cascadia, south Alaska, SWJapan, and Chile. Journal of Geophysical Research Atmospheres 1041(B7), 14965-14992.

Pacheco, J.F., Sykes, L.R., Scholz, C.H., 1993. Nature of seismic coupling along simple plate boundaries of the subduction type. Journal of Geophysical Research Atmospheres 98(981), 14133-14159.

Ranero, C.R., Morgan, J.P., Mcintosh, K., Reichert, C., 2003. Bending-related faulting and mantle serpentinization at the Middle America trench. Nature 425(6956), $367-73$.

Ruff, L., Kanamori, H., 1980. Seismicity and the subduction process. Physics of the Earth and Planetary Interiors 23(3), 240-252.

Sandwell, D.T., Smith, W.H.F., 1997. Marine gravity anomaly from geosat and ers 1 satellite altimetry. Journal of Geophysical Research Solid Earth 102(B5), 10039-10054.

Scholz, C.H., Small, C., 1997. The effect of seamount subduction on seismic coupling. Geology 25(6), 487-490.

Schubnel, A., Brunet, F., Hilairet, N., Gasc, J., Wang, Y., 2013. Deep-focus earthquake analogs recorded at high pressure and temperature in the laboratory. Science 341(6152), 1377-1380.

Seama, N., Okino, K., 2015. Asymmetric Seafloor Spreading of the Southern Mariana 
Trough Back-Arc Basin. Subseafloor Biosphere Linked to Hydrothermal Systems. Springer Japan 253-260.

Seno, T., Maruyama, S., 1984. Paleogeographic reconstruction and origin of the Philippine Sea. Tectonophysics 102, 53-84.

Seno, T., Stein, S., Gripp, A.E., 1993. A model for the motion of the Philippine Sea plate consistent with NUVEL-1 and geological data. Journal of Geophysical Research Atmospheres 98(B10), 17941-17948.

Shi, X.J., 1998. Spatial differences of the earthquake distribution along the island-arcs in the Western Pacific and their causes. Seismology and Geology 20(4), 309-404.

Singh, S.C., Hananto, N., Mukti, M., Robinson, D.P., Das, S., Chauhan, A., Carton, H., Gratacos, B., Midnet, S., Djajadihardja, Y., Harjono, H., 2011. Aseismic zone and earthquake segmentation associated with a deep subducted seamount in Sumatra. Nature Geoscience 4(5), 308-311.

Simmons, N.A., Myers, S.C., Johannesson, G., Matzel, E. 2012. Llnl-g3dv3: global P-wave tomography model for improved regional and teleseismic travel time prediction. Journal of Geophysical Research Atmospheres 117(B10), 189-200.

Staudigel, H., Clague, D.A., 2010. The geological history of deep-sea volcanoes: Biosphere, hydrosphere and lithosphere interactions. Oceanography 23(1), 58-71.

Staudigel, H., Koppers, A.A.P., Plank, T.A., Hanan, B.B., 2010. Seamounts in Subduction Factory. Oceanography 23(1), 176-181.

Stern, R.J., Fouch, M.J., Klemperer, S.L., 2003. An overview of the Izu-Bonin-Mariana subduction factory. Inside the Subduction Factory 138, 175-222. 
Syracuse, E.M., Keken, P.E.V., Abers, G.A., 2010. The global range of subduction zone thermal models. Physics of the Earth and Planetary Interiors, 183(1-2): 73-90.

Watts, A.B., Koppers, A.A.P., Robinson, D., 2010. Seamount Subduction and Earthquakes. Oceanography 23(1), 166-173.

Watts, A.B., Sandwell, D.T., Smith, W.H.F., Wessel, P., 2006. Global gravity, bathymetry, and the distribution of submarine volcanism through space and time. Journal of Geophysical Research Solid Earth 111(B8), 137-145.

Wei, W., Xu, J., Zhao, D., Shi, Y., 2012. East Asia mantle tomography: New insight into plate subduction and intraplate volcanism. Journal of Asian Earth Sciences 60, 88-103.

Woodcock, N.H., Daly, M.C., 1986. The role of strike-slip fault systems at plate boundaries [and discussion]. Philosophical Transactions of the Royal Society B Biological Sciences 317(1539), 27-29.

Xing, J., Hao, T.Y., Hu, L.T., Suh, M., Kim, K.W., 2016. Characteristics of the Japan and IBM subduction zones: Evidence from gravity and distribution of earthquake sources. Chinese Journal of Geophysics 59(1), 116-140.

Yamazaki, T., Seama, N., Okino, K., Kitada, K., Joshima, M., Oda, H., Naka, J., 2003. Spreading process of the northern Mariana Trough: rifting-spreading transition at $22^{\circ}$ N. Geochemistry Geophysics Geosystems 4(9).

Zhan, Z., Kanamori, H., Tsai, V.C., Helmberger, D.V., Wei, S., 2014. Rupture complexity of the 1994 Bolivia and 2013 Sea of Okhotsk deep earthquakes. Earth and Planetary Science Letters 385(1), 89-96. 
Zhao, D.P., 2012. Tomography and dynamics of Western-Pacific subduction zones. Monographs on Environment Earth and Planets 1(1), 1-70.

Zhao, D., 2015. The 2011 Tohoku earthquake (Mw 9.0) sequence and subduction dynamics in Western Pacific and East Asia. Journal of Asian Earth Sciences 98, 26-49.

Fig.1. Map of the Izu-Bonin-Mariana subduction zone with the major mid-ocean ridges and transform faults. Topography is from ETOPO1 (Amante and Eakins, 2009). Thick red line denotes a tear identified by a seismic spatial distribution (Gvirtzman and Stern, 2004) and purple line denotes a probable tear identified by three-dimensional slab morphology (Miller et al., 2006).

Fig.2. (a) Map of 1973-2015 earthquakes $\left(M_{w}>5\right)$ epicenters (from USGS catalog) along the Izu-Bonin-Mariana subduction system. Red dots stand for shallow-depth earthquakes (depth $\leqslant 60$ km); Yellow dots stand for intermediate-depth earthquakes $(60<$ depth $\leqslant 300 \mathrm{~km})$; Blue dots stand for deep (>300 km) earthquakes. The Izu-Bonin-Mariana trench axis is grouped into 65 parts by black dots which interval is about $50 \mathrm{~km}$. Each part is made up of two green lines, and the green line is vertical to the trench cross black dot and the subducting plate interface (grey lines from Slab 1.0, Hayes et al., 2012) as much as possible. Three parallel purple lines ( $\left.A-A^{\prime}, B^{\prime}-B^{\prime}, C^{\prime}-C^{\prime}\right)$ represent three sections near the trench on the Pacific Plate. (b) Three purple curves(A-A', B-B', C-C') show relief amplitudes near the trench. Peaks show locations of seamount or plateau. (c) Histograms show the relationship between the number of earthquakes and relative location along the Izu-Bonin-Mariana trench. Three histograms are corresponding respectively to shallow, 
intermediate and deep earthquakes of (a), and relative locations of $x$-axis are area index labeled by (a), which are also corresponding to $\mathrm{x}$-axis of (b).

Fig.3. Focal mechanisms of three sections Map in Fig.2a (Dziewonski et al., 1981). Green line denotes bathymetry and red line denotes free air anomaly (Sandwell and Smith, 1997). Red triangles denote volcanoes.

Fig.4. Vertical cross-sections of percent perturbation relative to the $\mathrm{P}$ wave mean value along six profiles shown on the map (Simmons et al., 2012). (a) Blue color denotes high velocity, while red color denotes low velocity. White dots stand for hypocenters of earthquakes (>M5) during 1973-2015. The thick black lines denote the upper boundary of the subudcting Pacific slab from slab 1.0 (Hayes et al.,2012). Two thin black lines denote respectively $410 \mathrm{~km}$ and $660 \mathrm{~km}$ discontinuous interface. (b) Map shows locations of six profiles. Contours (slab 1.0) denote the upper boundary of the subducting slab and different color denotes different depth which interval is $20 \mathrm{~km}$.

Fig.5. Cartoon illustrating the shapes of subduction slabs and seismic spatial distributions beneath the Izu-Bonin and Mariana Arc. Note that dashed black lines only shows a northern Mariana type, both sides of which may be short plates (Fig.4D-D' and F-F'), where intermediate and deep earthquakes are absent. The yellow colors denote the subducting lithosphere and the blue colors denote high $\mathrm{Vp} / \mathrm{Vs}$ ratio which is corresponding to double seismic zone. Cartoon is modified based on Ii et al.(2010). 
Fig.6. A three-dimensional shape of the subducting slab and seismic spatial distribution beneath the IBM arc. Purple polygon stands for the top boundary (slab 1.0) of the subducted Pacific Plate. The Izu-Bonin part shows a relatively continuous slab structure whereas the Mariana part is segmented. Dots stand for earthquakes. Red denotes shallow earthquakes and blue denotes deep earthquakes.

Fig.7. (a) Subduction rate which a relative motion between the Pacific Plate and the Mariana microplate along the IBM Arc (Gripp and Gordon, 2002). Black arrow denotes the subducting direction and length denote velocity magnitude. The numbers stand for values of specific velocity. (b) The relationship between shallow seismic events (Fig.2c) and subduction velocity. The correlation coefficient of them is 0.605 .

Fig. 8. Spreading half-rate along the Mariana axis (Deschamps and Fujiwara, 2003; Yamazaki et al., 2003; Deschamps et al., 2005; Seama and Okino, 2015). Thin black arrows denote the spreading direction along the red lines denoting the spreading axis based on the geomagnetic anomalies using the Matuyama-Brunhes boundary $(0.78 \mathrm{Ma})$; black numbers denote half-rate values; violet arrows denote subduction rates along the Mariana Arc (Gripp and Gordon, 2002). Circles denote earthquakes. 


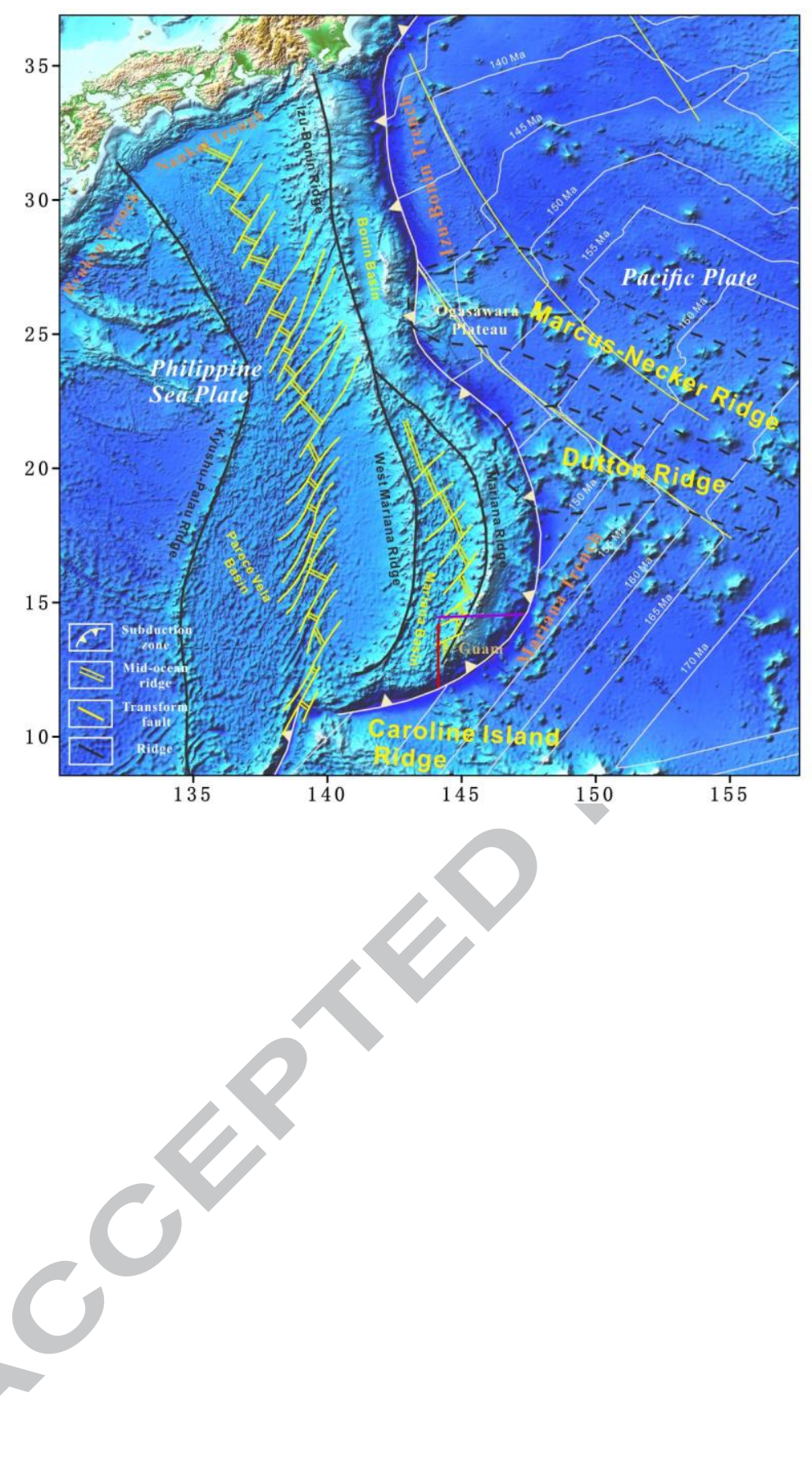



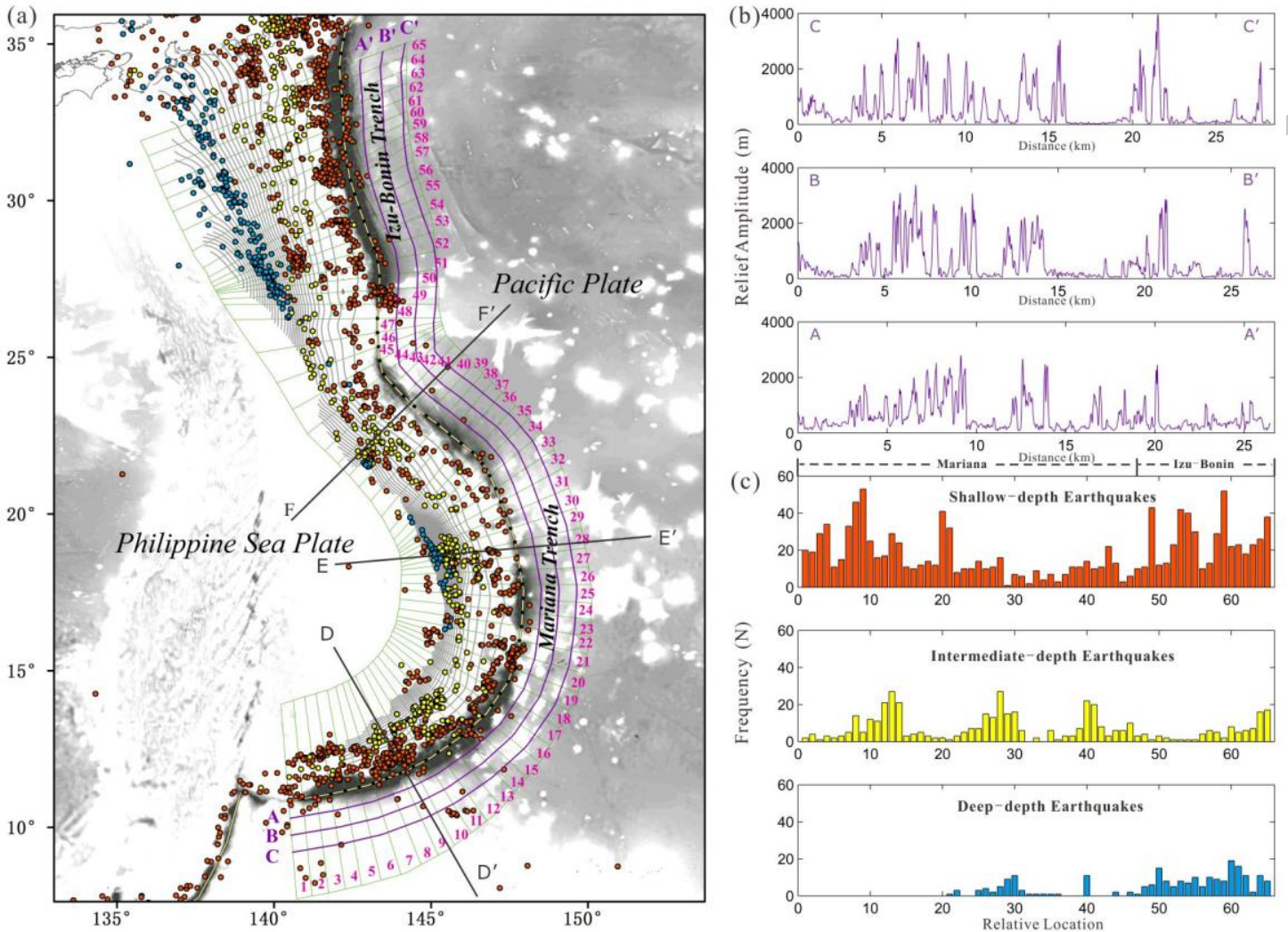

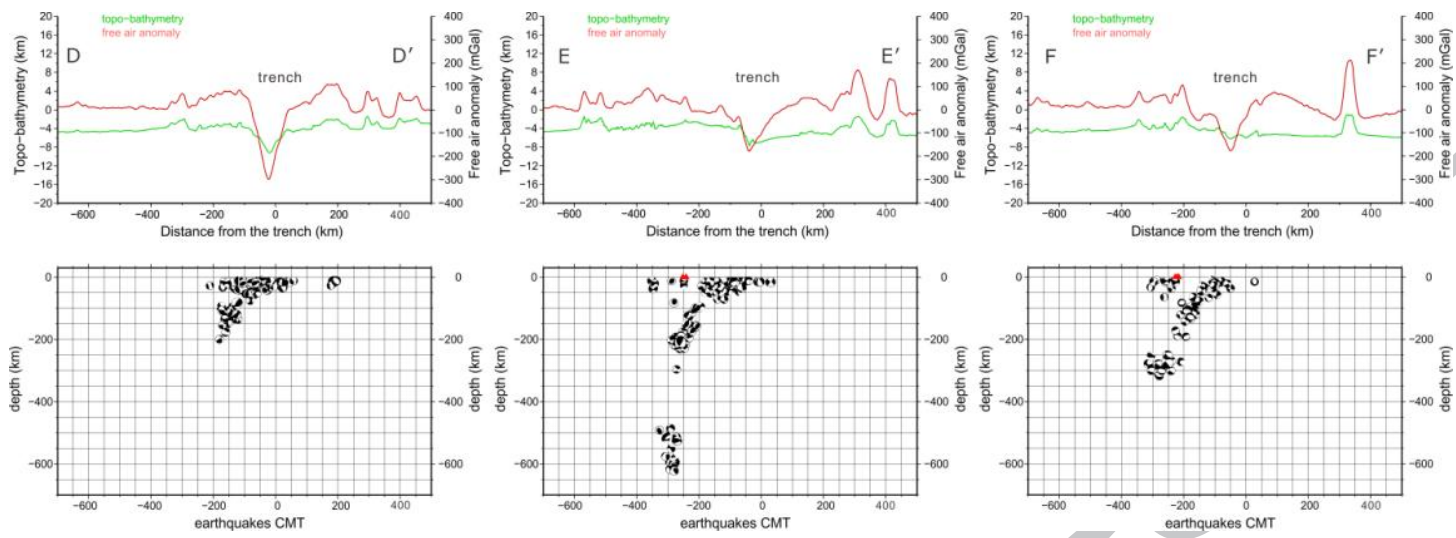
(a)
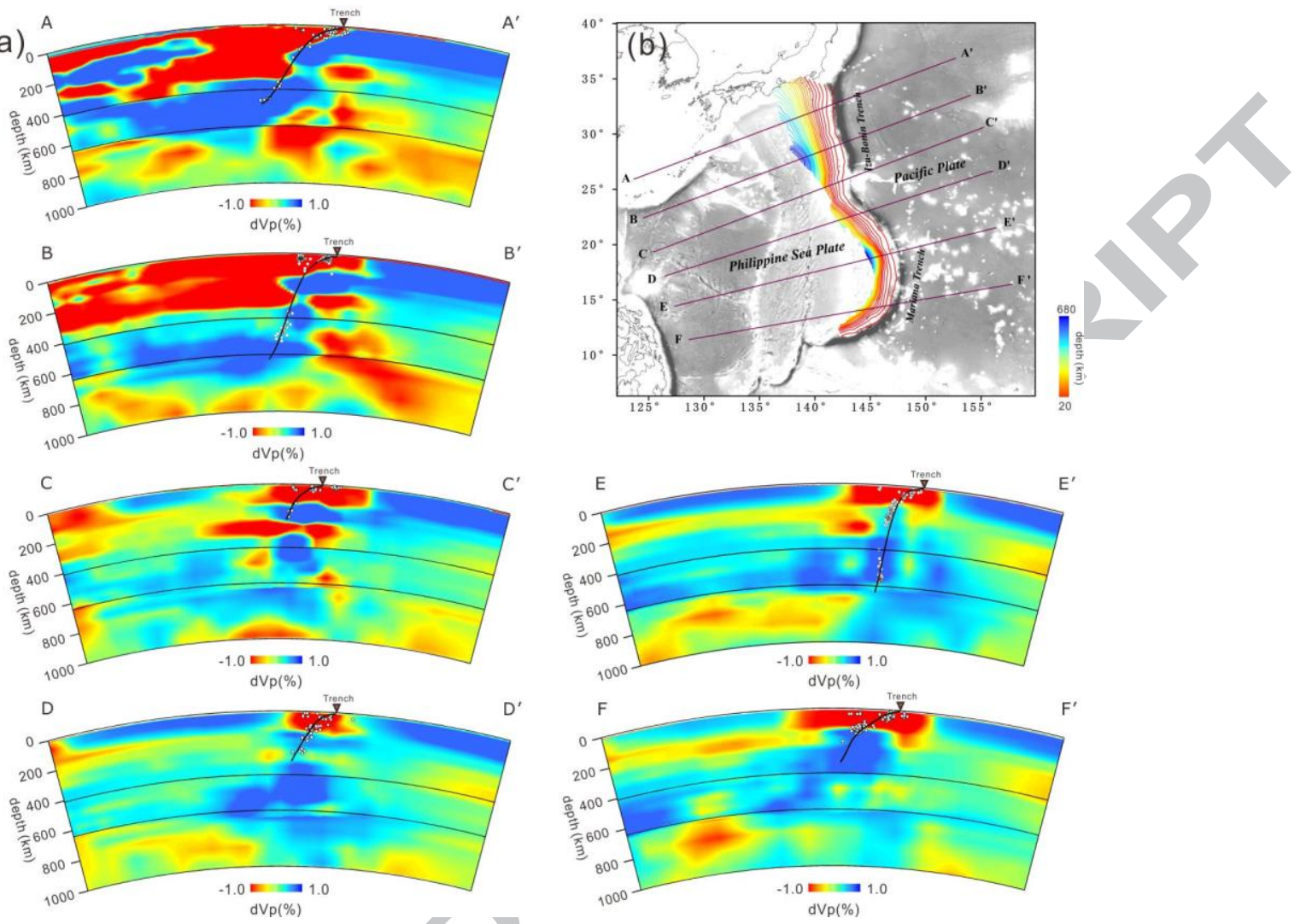


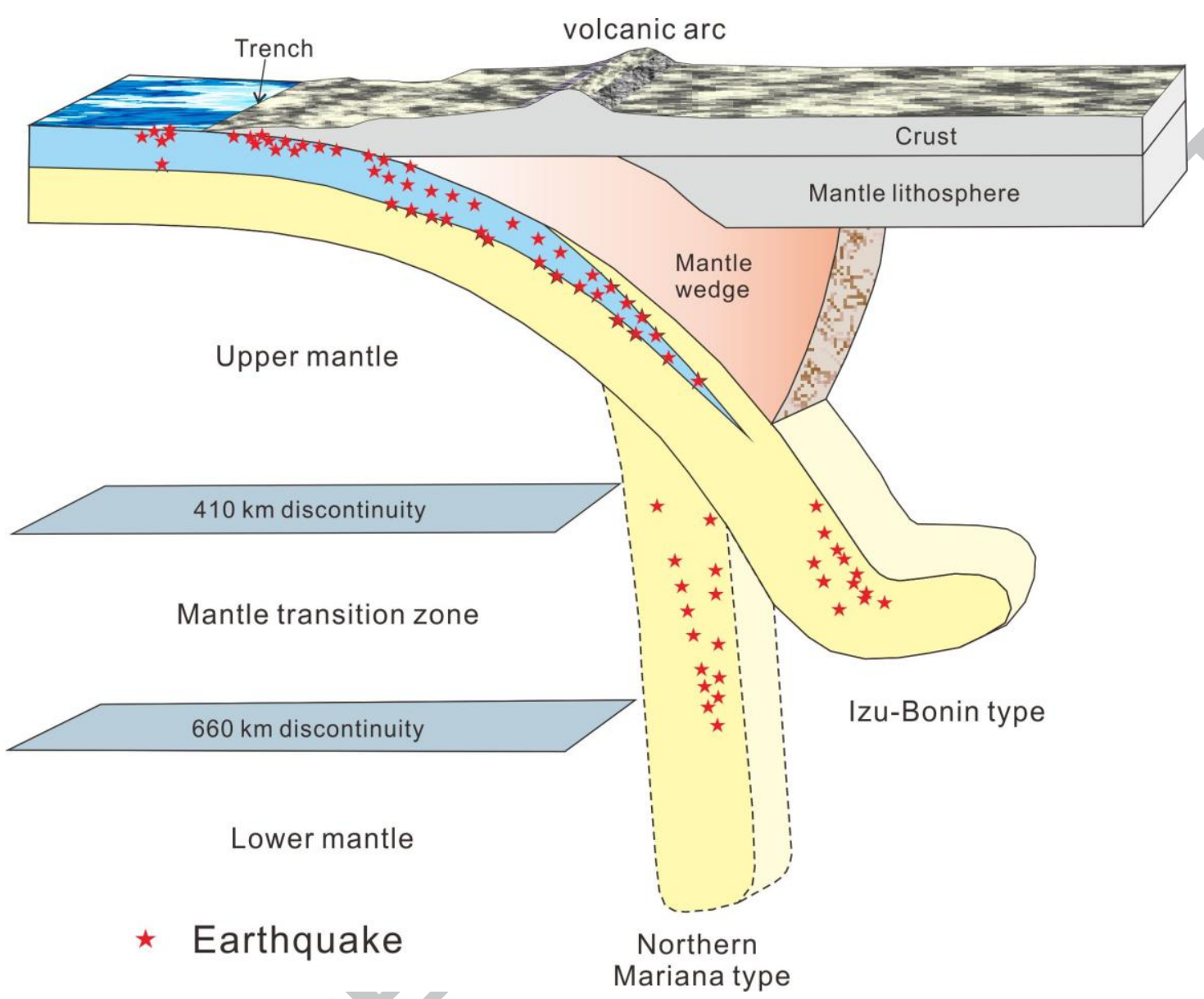




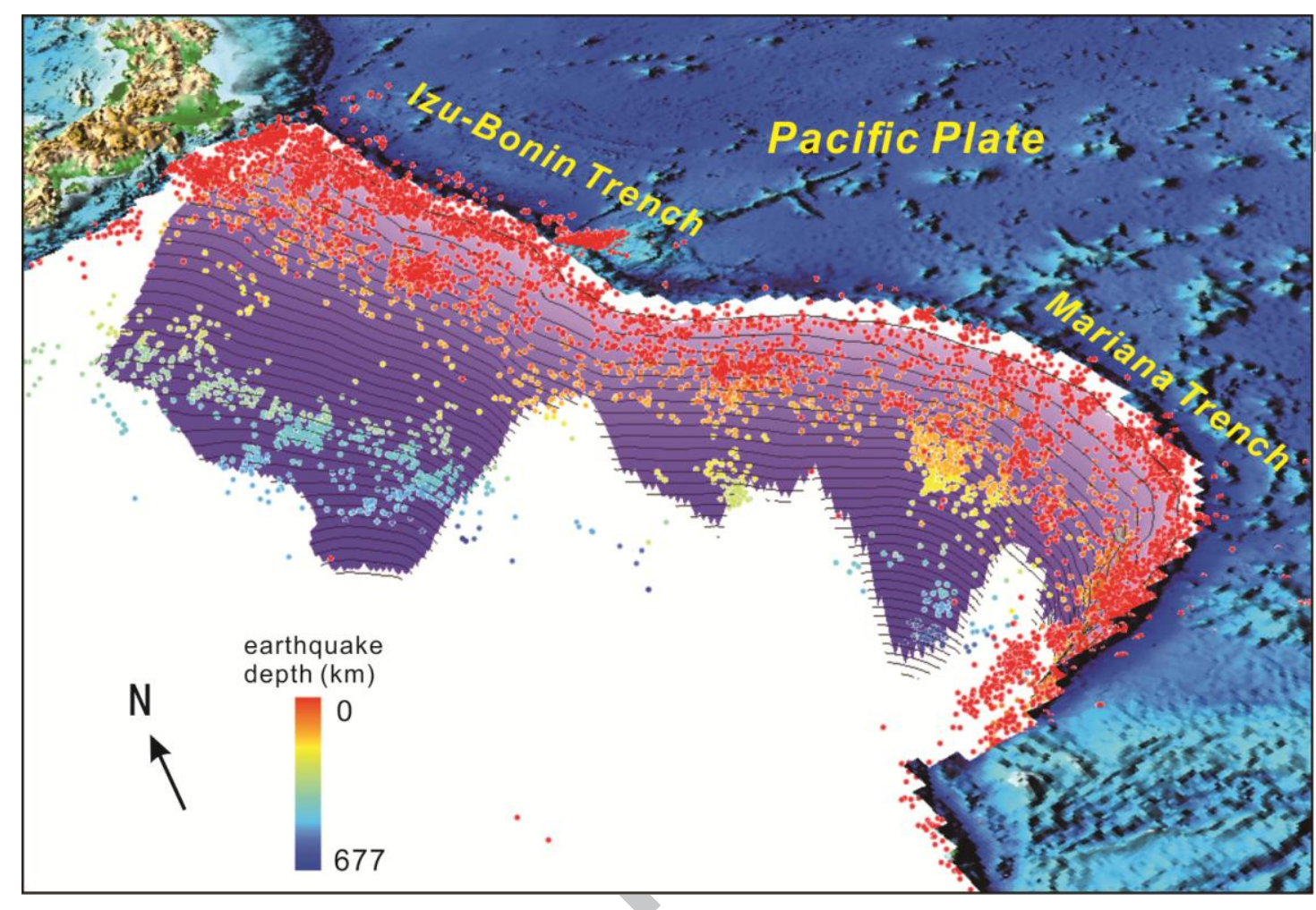




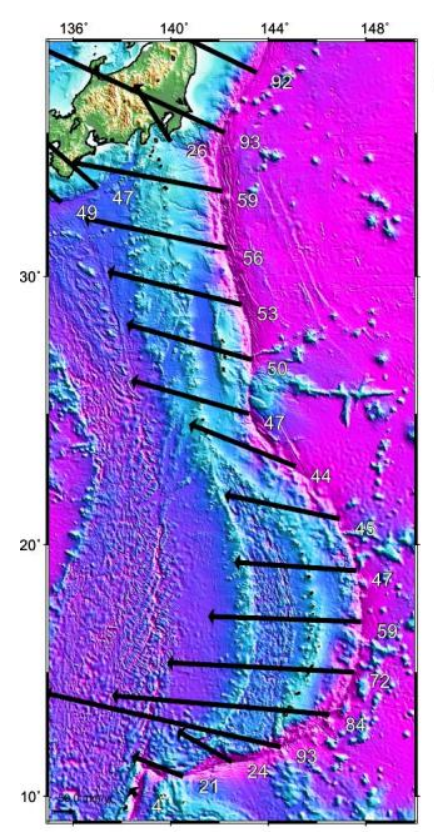

(a)

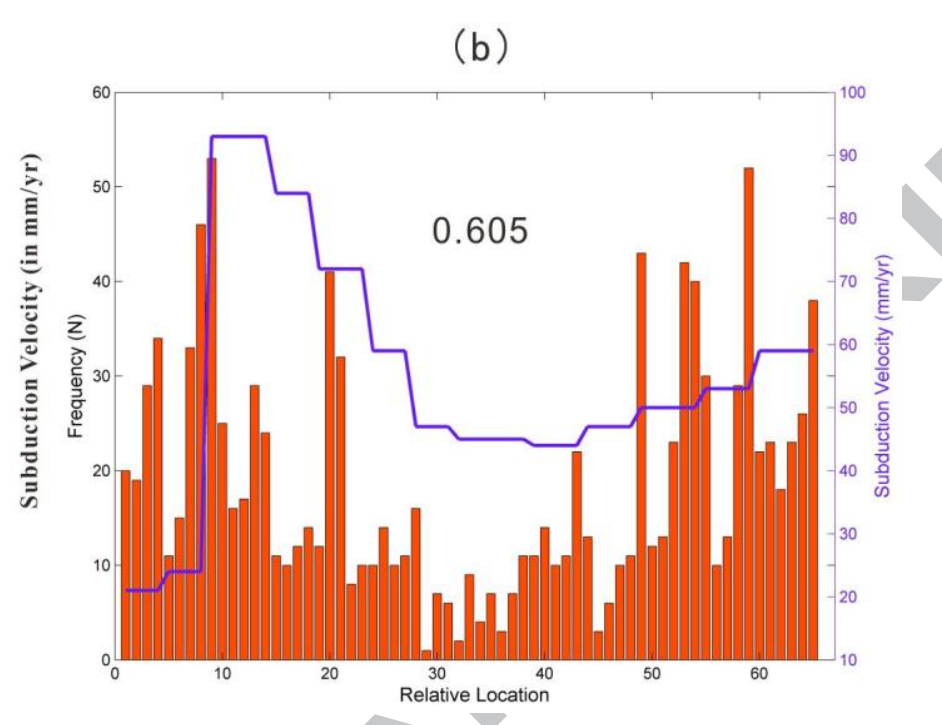




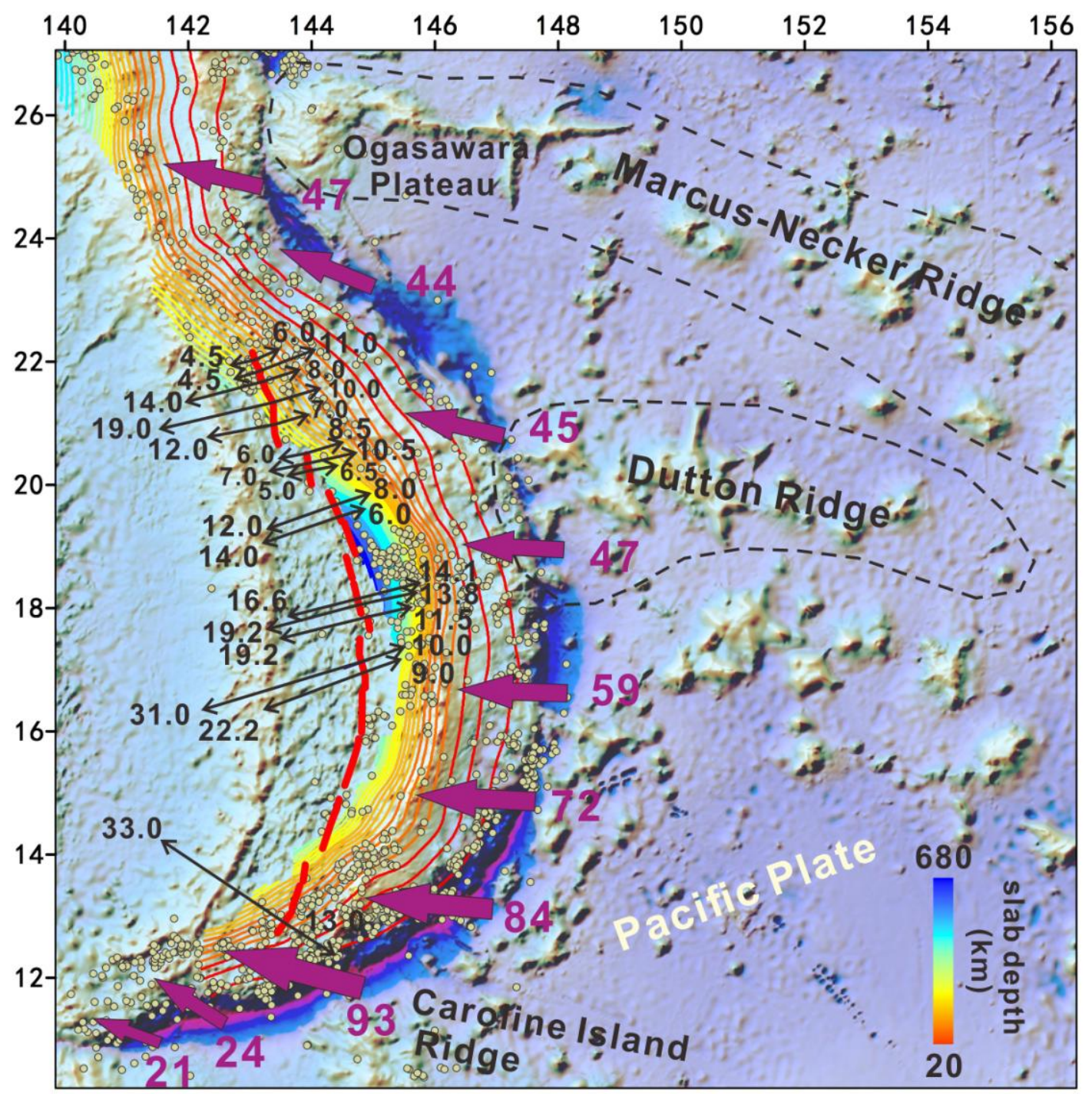


Graphical abstract
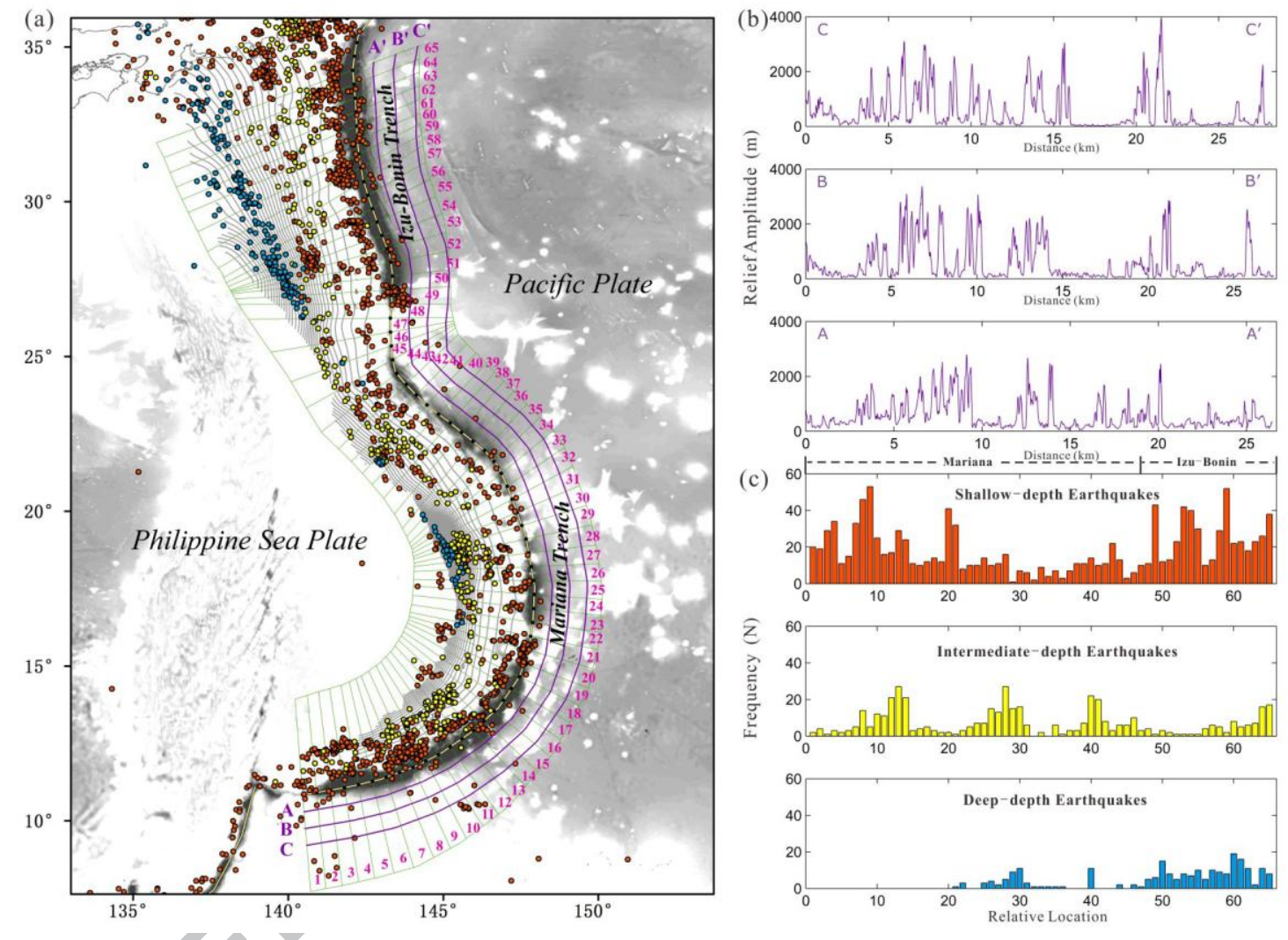